\title{
Thrombosed aneurysm of the ductus diverticulum mimicking malignancy on 18F-FDG PET/CT
}

\author{
Rajesh Thampy, Varaha S Tammisetti, Chakradhar R Thupili
}

Department of Diagnostic and Interventional Imaging, McGovern Medical SchoolUTHealth, Houston, Texas, USA

\section{Correspondence to} Dr Rajesh Thampy, rajesh.thampy@uth.tmc.edu

Accepted 22 November 2018

\section{DESCRIPTION}

A 45-year-old woman with high-grade sarcoma of the right femur underwent 18 fluorine fluorodeoxyglucose positron emission tomography (18F-FDG PET/CT) for metastatic workup. The 18F-FDG PET/CT showed an FDG-avid soft-tissue mass in the aortopulmonary window (figure 1). Given the history of malignancy, the diagnosis of metastasis was considered, and biopsy was recommended. But since there were no lymph nodes elsewhere, contrast-enhanced CT scan was done to rule out a vascular lesion prior to biopsy. Contrast-enhanced CT scan of the chest showed soft-tissue density mass between the aortic arch and pulmonary artery in the expected location of ductus arteriosus (figure 2). The characteristic location of the mass between the aortic arch and pulmonary artery, with contrast outpouching from the aortic arch extending to the soft-tissue mass confirmed the diagnosis as thrombosed aneurysm of the ductus diverticulum (figures 2 and 3 ).

Aneurysm of the ductus diverticulum is an extremely rare entity and is usually misdiagnosed as malignancy of the aortopulmonary window or atherosclerotic aortic arch aneurysm. Ductus arteriosus is a small blood vessel in the fetus connecting the aortic arch and pulmonary artery. After birth, it closes to form the ligamentum arteriosum. The pulmonary end is usually closed but a small focal bulge may persist at the aortic site along the undersurface of the aortic arch to form the ductus diverticulum. ${ }^{1}$ An aneurysm forms when this bulge dilates due to increased pressure as in hypertension and atherosclerosis. In our patient, there was near
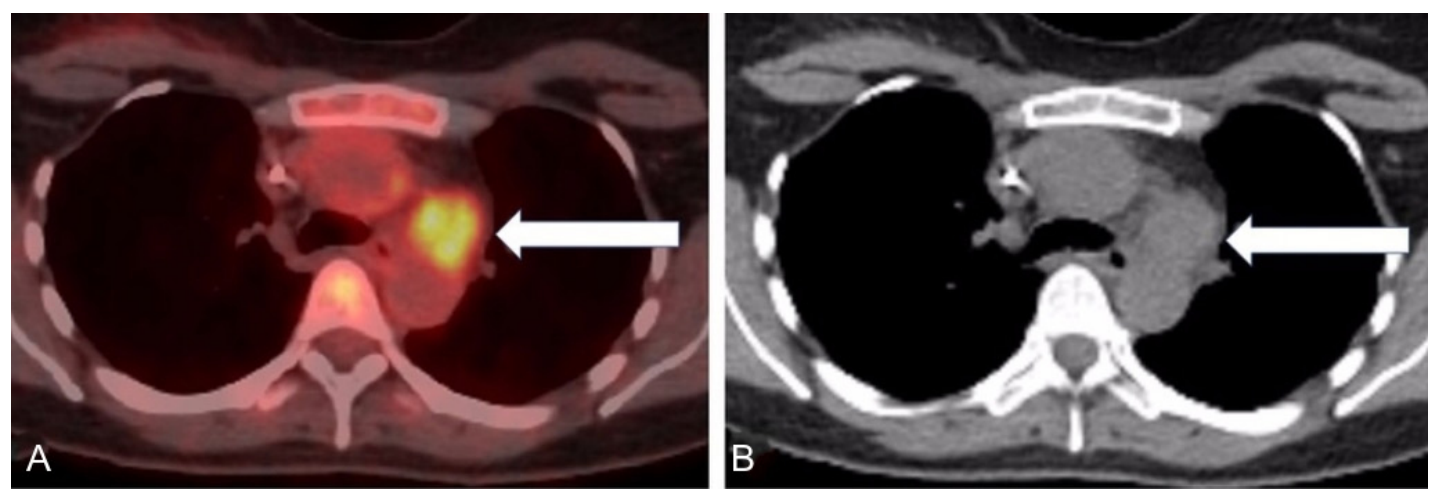

Figure 1 Axial fusion PET-CT image (A) and CT image (B) of the chest shows FDG-avid mass (white arrows) in the aortopulmonary window.
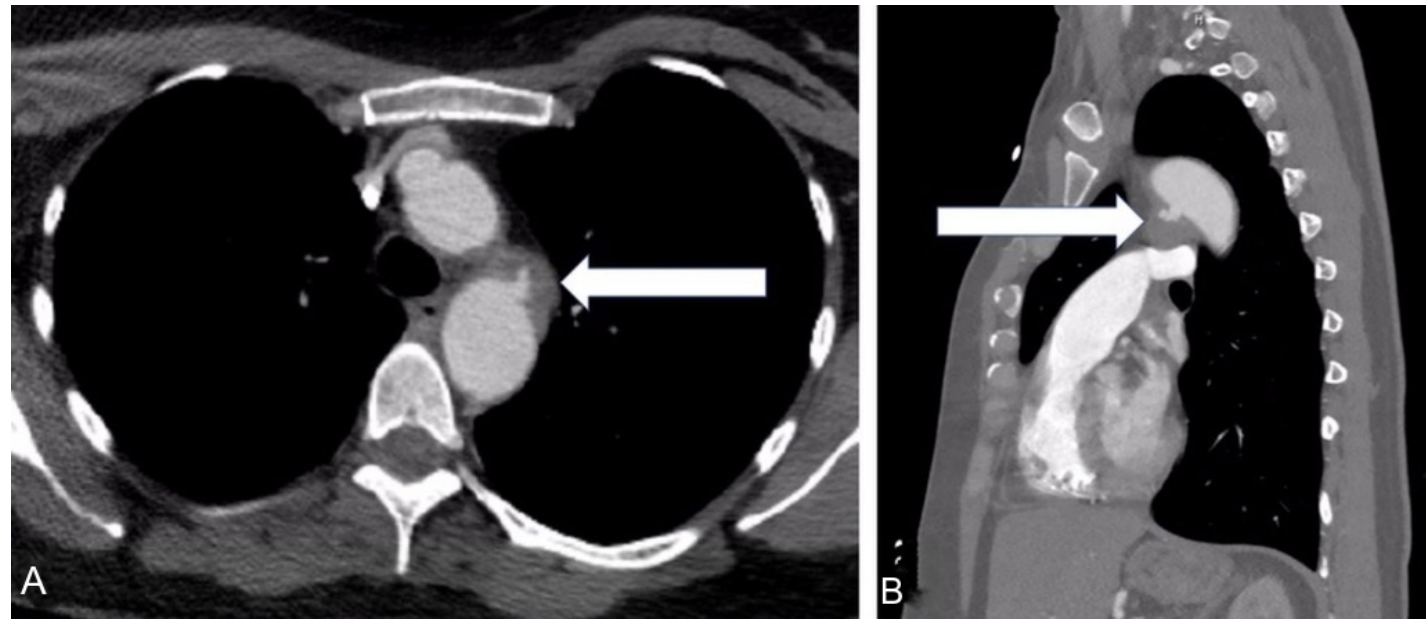

Figure 2 Contrast-enhanced CT scan of the chest axial (A) and sagittal (B) images shows soft-tissue density mass (white arrows) between the aortic arch and pulmonary artery indenting the pulmonary artery. Contrast outpouching from the aorta extends to the mass confirming the diagnosis of thrombosed aneurysm of the ductus diverticulum. 


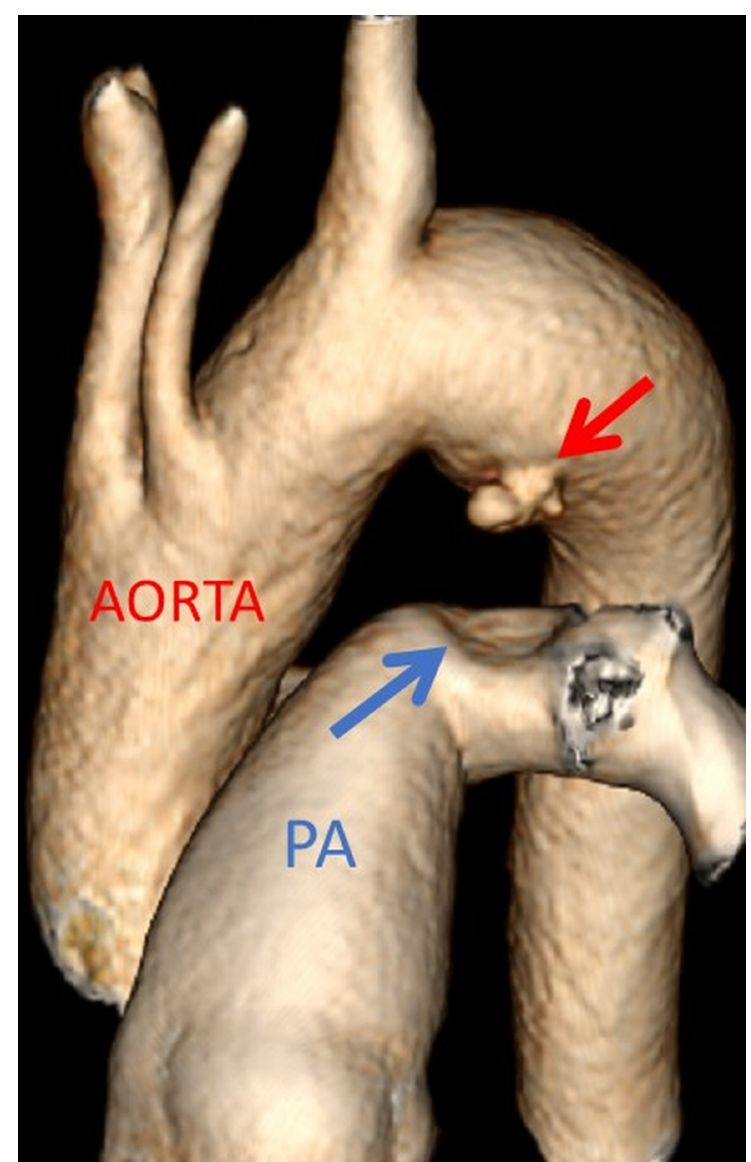

Figure 3 Three-dimension volume rendered CT image depicting outpouching (red arrow) of the ductus aneurysm from the aortic arch distal to the left subclavian artery directed towards the pulmonary artery (PA). Indentation is seen on the pulmonary artery caused by the thrombosed portion of the aneurysm (blue arrow).

complete thrombosis of the aneurysm which produced a softtissue density mimicking lymph node metastasis on non-contrast CT. The diagnosis was further confounded by hypermetabolism of the mass on 18F-FDG PET/CT, suggestive of malignancy.
18F-FDG PET/CT has high sensitivity for detecting malignancy but is not specific because inflammation can also show FDG uptake. Reports have shown that benign thrombosis can also be FDG avid. ${ }^{2}$ The increased FDG uptake in thrombosis is believed to be due to either inflammatory cells infiltrating the thrombus or accumulation of inflammatory cells in the wall of the aneurysm. However, contrast outpouching from the aortic arch extending to the mass on CT confirmed the diagnosis of partially thrombosed ductus diverticulum aneurysm. ${ }^{2}$

Ductus diverticulum aneurysms are more prone to rupture and frequently fatal compared with saccular atherosclerotic aneurysms. ${ }^{3}$ They are surgically repaired by thoracotomy and resection or by endovascular stent graft. ${ }^{4}$

\section{Learning points}

- Thrombosed ductus diverticulum aneurysm can be misdiagnosed as malignancy/lymphadenopathy and inadvertent biopsy of this lesion can be catastrophic.

- Characteristic location between the aorta and pulmonary artery with contrast outpouching from the aorta confirms the diagnosis.

Contributors CRT conceived the case report. RT and VST were major contributors towards writing the manuscript. CRT and RT interpreted the patient data. RT did the image reconstructions. All authors read and approved the final manuscript.

Funding The authors have not declared a specific grant for this research from any funding agency in the public, commercial or not-for-profit sectors.

Competing interests None declared.

Patient consent for publication Obtained.

Provenance and peer review Not commissioned; externally peer reviewed.

\section{REFERENCES}

1 Agarwal PP, Chughtai A, Matzinger FR, et al. Multidetector CT of thoracic aortic aneurysms. Radiographics 2009;29:537-52.

2 Kikuchi M, Yamamoto E, Shiomi Y, et al. Case report: internal and external jugular vein thrombosis with marked accumulation of FDG. Br J Radiol 2004;77:888-90.

3 Mitchell RS, Seifert FC, Miller DC, et al. Aneurysm of the diverticulum of the ductus arteriosus in the adult. Successful surgical treatment in five patients and review of the literature. J Thorac Cardiovasc Surg 1983;86:400-8.

4 Saito N, Kimura T, Toma M, et al. Successful endovascular repair of an aneurysm of the ductus diverticulum with a branched stent graft: case report and review of literature. J Vasc Surg 2004;40:1228-33.

Copyright 2018 BMJ Publishing Group. All rights reserved. For permission to reuse any of this content visit https://www.bmj.com/company/products-services/rights-and-licensing/permissions/

BMJ Case Report Fellows may re-use this article for personal use and teaching without any further permission.

Become a Fellow of BMJ Case Reports today and you can:

- Submit as many cases as you like

- Enjoy fast sympathetic peer review and rapid publication of accepted articles

- Access all the published articles

- Re-use any of the published material for personal use and teaching without further permission

For information on Institutional Fellowships contact consortiasales@bmjgroup.com

Visit casereports.bmj.com for more articles like this and to become a Fellow 